\title{
Early Surgical Adverse Events and Incidence Rates in Bidirectional Barb Suspension Thread Surgery
}

\author{
Dr. Kacey HAU* \\ Dermatologist in Perfect Skin Surgery Centre, Central, Hong Kong. \\ *Correspondence: \\ Dr. Kacey HAU, Dermatologist in Perfect Skin Surgery Centre: 17/F, \\ Hing Wai Building, 36 Queen's Road Central, Central, Hong Kong. \\ Received: 21 July 2019; Accepted: 28 August 2019
}

Citation: Kacey HAU. Early Surgical Adverse Events and Incidence Rates in Bidirectional Barb Suspension Thread Surgery. Dermatol Res. 2019; 1(2); 1-3.

\begin{abstract}
Background: There is a constant upsurge in the use of minimal invasive surgery in aesthetic practice globally. Barb thread suspension has been used to reshape and reposition facial contour. However, the safety, incidence of adverse events is not well defined.
\end{abstract}

Objectives: To study the incidence of adverse events in the first four weeks after thread surgery.

Results: The incidence of adverse events at week four is 5.5\%. Most of them are mild (5\%). Significant events include parotid gland tear and surgical site infection. Majority of the patients (86\%) and the physicians (89\%) give a global score for the recovery issues from none to mild and acceptable.

Conclusion: Barb suspension surgery is a safe office-based procedure. Among different variables, standardized surgical protocol, sterile handling and hands-on training may help to secure the safety.

\section{Keywords}

Barb suspension surgery, Double needle thread, Incidence, Adverse events, Complications.

\section{Introduction}

Among the surgical arena for reshaping and redraping the contour of our ageing face, currently one may resort to suture thread materials or other energy-based devices or formal face-lifting surgery. There is a constant upsurge in the application of thread suspension surgery globally. Sterilization and synthetic polymers that degrade in a commensurate fashion with wound healing have been the most significant improvements in these age-old suture devices in surgical practice. The evolution of barbed suture technologies and their application in the field of plastic surgery is now in its third decade [1].

Face-lifting is the 4th commonest surgical procedure globally [2]. Barb suspension thread can be an alternative option to formal surgery as thread surgery is minimal invasive, office-based procedure, bearing lower risks and less down time. Successful thread use started in $50 \mathrm{~s}$ and later with the introduction of permanent thread system by Sulamanidze in late 90 s [3].

Designs developed primarily for use in aesthetic facial procedures include free-floating, bidirectionally barbed sutures; unidirectional barbed sutures; anchored, bidirectional double- threaded sutures. In summary, the major thread system in the market are barb and smooth suture materials. In the barb suture, it can be either unidirectional and bidirectional barb system. Theoretically, bidirectional barb thread system can give better mechanical advantage by positioning more barb in the suspension and the antagonistic traction between the barbs in two opposite directions [4].

In addition to the mechanical traction created by barb suture, the tissue-suture interaction or biostimulation may play a role in aesthetic outcome. The long-term results once after the resolution of the physical thread materials also relies on the effective biostimulation. There is an upsurge of thread materials in aesthetic arena and the use are increasingly common. The composition, design and the clinical applications dictate the product and as a result the treatment outcome specificities. With more understanding 
on the facial anatomy and the tissue interaction with the physical composition we can define the treatment outcome by the physical traction and biostimulation effects [5].

Barb suspension surgery is getting popular as a supplementary choice for facial contouring and reshaping. Compared with formal face lifting, barb suspension provides a safer, minimally invasive and office-based surgical procedure. With the downward trend in the numbers of formal face-lifting surgery globally, barb suspension thread surgery can be a useful adjunct and serves the purpose of minimally-invasive surgery $[6,7]$.

However, barb suspension procedure does have certain risks due to the invasive nature. Further, the foreign materials that retaining inside underneath the skin might create further tissue interactions like granuloma or foreign body reaction. Likewise, in other medical procedures involving the placement of foreign materials, there are risks of infection, and sometimes can be delayed in onset. There are reports in the literature about different adverse events related to the thread surgery but the incidence of the procedure is not well defined [6,8-10].

Adverse surgical events in aesthetic practice can be delayed recovery (significant downtime such as bruises or pain), unsatisfactory aesthetic outcomes or complications like infection or tissue organ injury such as parotid gland injury $[11,12]$.

\section{Objectives}

We would like to evaluate the incidence of adverse events after thread suspension procedure. Through this retrospective analysis, we would like to standardize and define the possible adverse events to facilitate future reporting and prevention strategies.

\section{Methodology}

\section{Materials}

We use Happy Lift ${ }^{\mathrm{TM}}$ (Revitalizing) Double Needle threads (or in Europe and some other countries known as Definisse ${ }^{\mathrm{TM}}$ threads). This is a range of absorbable, monofilament, suspension-barbed threads of synthetic origin (poly-L-lactic acid and caprolactone, $\mathrm{p}(\mathrm{LA}-\mathrm{CL})$. The thread ends have two straight sharp needles 100 $\mathrm{mm}$ long with a diameter of $0.462-0.488 \mathrm{~mm}$ for the thread with the $12 \mathrm{~cm}$ barbed section. The thread with the $23 \mathrm{~cm}$ barbed section has two $150 \mathrm{~mm}$ long needle with the same diameter. The barbs distribution is bidirectional and convergent. The sutures interact with the tissues with a double action.

The first one is the immediate lifting action for the support and repositioning of the tissues, thanks to the mechanical action determined by the anchoring of threads barbs once inserted in the tissue. The second is the revitalizing action, due the fibrosis and slight inflammation that is determined along the thread.

\section{Procedure}

The field of procedure involves midface, lower face and neck areas. The procedure is performed under local anaesthesia with adrenaline using standard aseptic technique in all cases.
Depending on the vector for reshaping, the surgical procedures are standardized into five categories [13] for different approaches of facial reshaping as follows:

Techniques with lateral vectors (percentage of cases):

- Jawline Reshaping (JR) that corrects the defects of jawline due to inferior jowl fat ptosis (18\%);

- Malar Reshaping (MR) that lifts laterally the malar fat pad (37\%);

- Lateral Reshaping (LR) that lifts laterally the midface and lower face fat compartment combining the actions of previous techniques $(13 \%)$.

Techniques with vertical vectors:

- Oval Reshaping - Vertical Reshaping(ORV) that lifts vertically the central and medial fat compartments of cheek (18\%);

- Oval Vertical Reshaping-H (ORH) that lifts vertically the central and medial fat compartments of cheek (14\%).

All the techniques include an entry point, two exit points, sometimes an intermediate point and the thread sutures lie in the sub-SMAS plane under the preoperatively designed reshaping lines that indicate the direction of thread insertion.

\section{Post-operative care}

All patients were discharged with standard dressing materials including chlorhexidine, fusidic acid or equivalent ointment and paracetomol after the procedure. The patients were followed up one week, two weeks and four weeks after surgery. All the recorded adverse events are defined in Table One.

\section{Documentation and data collection}

The adverse events are stratified according to defined categories using Microsoft Excel $\AA^{\circledR}$. Photos were taken for documentation after patients' consent.

\begin{tabular}{|c|c|}
\hline Adverse outcome & Definition \\
\hline Headache & $\begin{array}{c}\text { Sudden onset of headache after the procedure with } \\
\text { unprecedented history }\end{array}$ \\
\hline Redness & Persistence of erythema after 24 hours \\
\hline Swelling and bruising & Persistence of swelling and bruising after one week \\
\hline $\begin{array}{c}\text { Persistent surgical site } \\
\text { pain }\end{array}$ & $\begin{array}{c}\text { Pain related to the barb thread location and/or pain } \\
\text { aggravated by facial movement in the thread path } \\
\text { like smiling, mastication and talking }\end{array}$ \\
\hline $\begin{array}{c}\text { Surgical site infection } \\
\text { Asymmetry }\end{array}$ & $\begin{array}{c}\text { Appearance of infection in the related surgical site } \\
\text { (puncture and/or thread path) in first 28 days }\end{array}$ \\
\hline $\begin{array}{c}\text { Asymmetry which is aesthetically unpleasant } \\
\text { Palpability/visibility of } \\
\text { threads }\end{array}$ & $\begin{array}{c}\text { Easy recognizable of underlying thread visually } \\
\text { from social distance or on simple palpation like } \\
\text { washing face }\end{array}$ \\
\hline Early recurrence & Reappearance of original facial laxity by 28 days \\
\hline $\begin{array}{c}\text { Protrusion and extrusion } \\
\text { a. Appearance of the thread outside or } \\
\text { b. tenting of the thread end }\end{array}$ \\
\hline $\begin{array}{c}\text { Injury of the local } \\
\text { anatomical parts }\end{array}$ & $\begin{array}{c}\text { Examples like parotid gland, vessels and nerves } \\
\text { with related sign and symptoms }\end{array}$ \\
\hline
\end{tabular}




\begin{tabular}{|c|c|}
\hline $\begin{array}{l}\text { Post-inflammatory } \\
\text { hyperpigmentation }\end{array}$ & $\begin{array}{l}\text { Appearance of pigmentation along the path or near } \\
\text { the path when edema resolves }\end{array}$ \\
\hline $\begin{array}{l}\text { Bunching, pleating and } \\
\text { dimpling }\end{array}$ & $\begin{array}{l}\text { a. unnatural folding of the skin due to traction or } \\
\text { mobilization of tissue by the thread; } \\
\text { b. depression related to the puncture site }\end{array}$ \\
\hline $\begin{array}{l}\text { Transient motor } \\
\text { paralysis of facial } \\
\text { muscles }\end{array}$ & $\begin{array}{l}\text { Partial weakness of facial muscles due to infiltration } \\
\text { of anaesthetic solution }\end{array}$ \\
\hline Others & $\begin{array}{l}\text { Alopecia, granuloma, allergic reaction, hematoma, } \\
\text { life threatening conditions }\end{array}$ \\
\hline
\end{tabular}

Table 1: Definition of all adverse events.

\section{Results}

Demographics

This is a single center retrospective cohort study on the surgical outcomes. A collection of 200 pairs of thread (patient number $\mathrm{n}=200$ ) used in the period of 2017-2019 (two years). These are all ethnic Hong Kong Chinese. Age range from 20 to 76 (mean 44.2). Male subjects accounts for $27 \%$.

The thread materials are either $12 \mathrm{~cm}$ (used in $76 \%$ of cases) or $23 \mathrm{~cm}$ in length. The surgery was either performed by the trainer or the author (KC HAU, $n=136,68 \%$ ) or by trainees attending the hands-on workshops under author's onsite supervision.

The incidence of adverse events is subsectored into 1. Mild (either improves with time, or manageable by simple, conservative and non-surgical intervention) and 2. Significant (needs active, aggressive or surgical intervention, one case of surgical site infection and one case of parotid gland injury). At Week 4, the incidence rate of adverse events is $5.5 \%$ (5.0\% mild, $0.5 \%$ significant).

Some of the adverse events are shown in the pictures below: Protrusion (week 2)

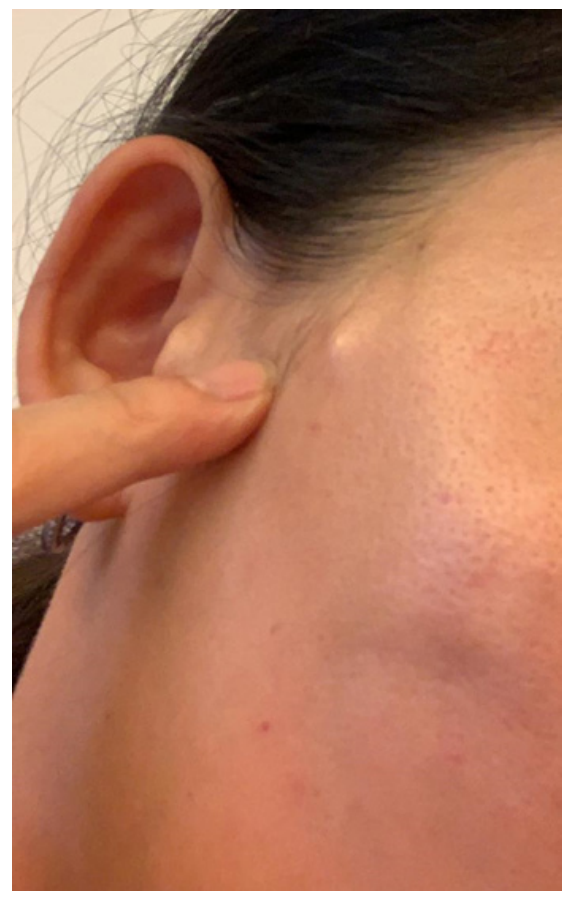

Extrusion (week 2)

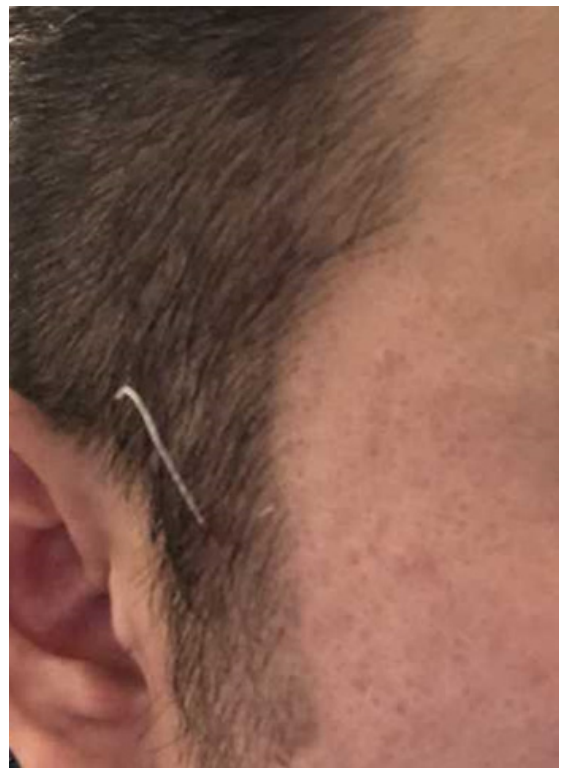

Bruise and traction (2 days)

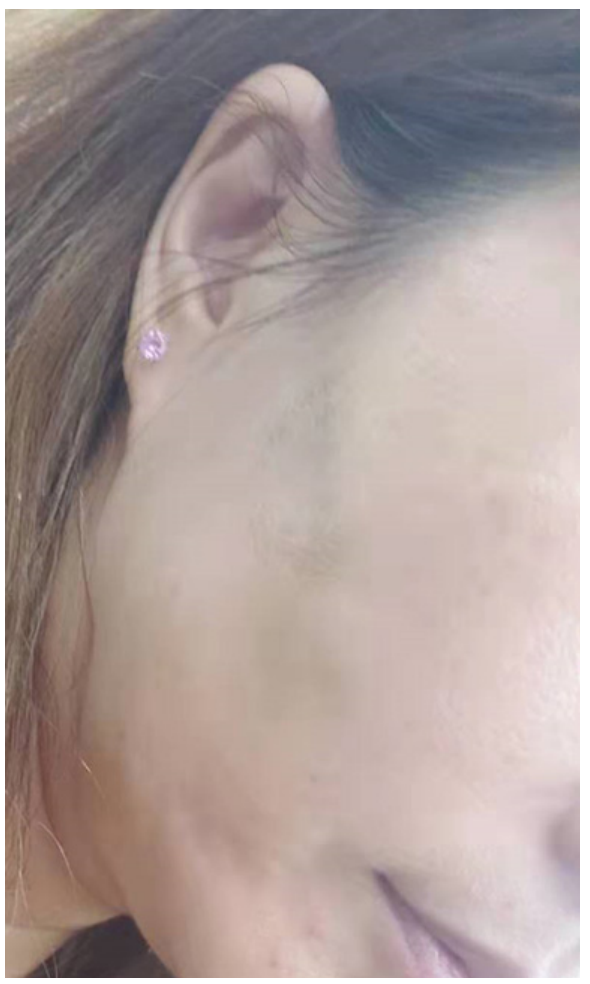

Transient muscle paralysis right after surgery (1 hour and last 2-3 hours with complete resolution)

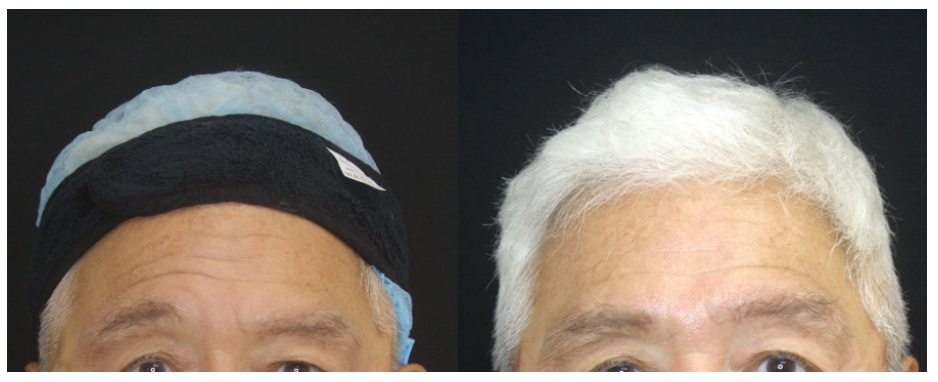

Volume 1 | Issue 2 | 3 of 5 
Dimpling (1 hour) and resolution (week 2)

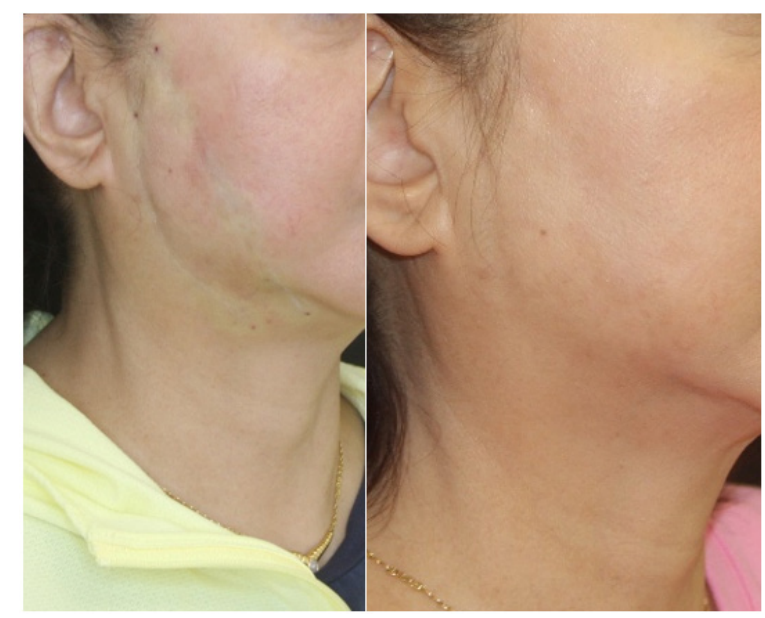

The reported adverse events in week one, week two and week four are summarized in table two.

\begin{tabular}{|c|c|c|c|c|}
\hline Adverse outcome & Week1 & Week2 & Week3 & Remarks \\
\hline Headache & 2 & 0 & 0 & \\
\hline Redness & 16 & 6 & 0 & \\
\hline $\begin{array}{l}\text { Swelling and } \\
\text { bruising }\end{array}$ & 26 & 12 & 0 & \\
\hline $\begin{array}{l}\text { Persistent surgical } \\
\text { site pain }\end{array}$ & 10 & 6 & 0 & \\
\hline $\begin{array}{l}\text { Surgical site } \\
\text { infection* }\end{array}$ & 0 & 0 & 1 & $\begin{array}{l}\text { Onset of purulent discharge } \\
\text { from entry point at day } \\
\text { 22, culture showed Staph. } \\
\text { Aureus; completely resolved } \\
\text { by drainage \& } 2 \text { weeks of } \\
\text { antibiotic. No extraction } \\
\text { needed }\end{array}$ \\
\hline Asymmetry & 6 & 1 & 0 & \\
\hline $\begin{array}{l}\text { Palpability/ } \\
\text { visibility of } \\
\text { threads }\end{array}$ & 6 & 3 & 0 & \\
\hline Early recurrence & 0 & 0 & 0 & \\
\hline $\begin{array}{c}\text { Protrusion and } \\
\text { extrusion }\end{array}$ & 2 & 12 & 5 & \\
\hline $\begin{array}{l}\text { Injury of the local } \\
\text { anatomical parts* }\end{array}$ & 1 & 0 & 0 & $\begin{array}{l}\text { parotid gland tear presented on } \\
\text { day one, completely resolved } \\
\text { by day seven with conservative } \\
\text { treatment. }\end{array}$ \\
\hline $\begin{array}{l}\text { Post-inflammatory } \\
\text { hyperpigmentation }\end{array}$ & 0 & 8 & 0 & \\
\hline $\begin{array}{l}\text { Bunching, pleating } \\
\text { and dimpling }\end{array}$ & 32 & 18 & 5 & \\
\hline $\begin{array}{l}\text { Transient motor } \\
\text { paralysis of facial } \\
\text { muscles }\end{array}$ & 6 & 0 & 0 & \\
\hline $\begin{array}{l}\text { Others (Alopecia, } \\
\text { granuloma, } \\
\text { allergic reaction, } \\
\text { hematoma, life } \\
\text { threatening } \\
\text { conditions) }\end{array}$ & 0 & 0 & 0 & \\
\hline Total: & 109 & 68 & 11 & \\
\hline
\end{tabular}

Table 2: Number of cases in each adverse event.
Finally, both physician and the subject gave a global score on the impact, severity and challenges in management related to the recovery from the thread surgery at week four (Figure 2).

\begin{tabular}{|c|c|c|}
\hline Category & $\begin{array}{c}\text { Client Global Score, } \\
\text { \% of subject choice }\end{array}$ & $\begin{array}{c}\text { Physician Global } \\
\text { Score, \% of cases }\end{array}$ \\
\hline None & 6 & 11 \\
\hline Mild and acceptable & 80 & 78 \\
\hline Significant but resolvable & 13 & 10 \\
\hline Significant and unacceptable & 1 & 1 \\
\hline $\begin{array}{c}\text { Permanent disfigurement or } \\
\text { disability }\end{array}$ & 0 & 0 \\
\hline
\end{tabular}

Table 3: Global score by clients and physician at week four.

\section{Discussion}

Office-based procedures have risen substantially every year. According to the American Society for Aesthetic Plastic Surgery (ASAPS), there was over approximately $5 \%$ increment each year. The art of aesthetic procedures, as well as from the expectations of the clienteles in this category require not only good aesthetic outcome, but also a tidy, swift and uneventful recovery. Overall, across all facilities, $1.9 \%$ of patients developed one major complications (2016). A 6-year retrospective review by Byrd et al demonstrated a complication rate of $0.73 \%$ [14], compared with $1.9 \%$ in another study by Gupta et al. [9]. Among these vascular complication like haematoma and infections were the major complication risks. In another study focusing on lasers, energy devices, and injectables neurotoxins and fillers, a complication rate of $0.24 \%$ is noted [8].

In thread surgery, the previous published results are more heterogenous. In this study we are able to demonstrate the postoperative progress of thread surgery. With the complication rate of $0.5 \%$ per patient or $0.25 \%$ per thread use, the rate of adverse events of thread suspension is close to that from other injectable procedures. There are several factors that we believe may contribute to control the rate of adverse events. All doctors performing the surgery are properly trained in terms of relevant clinical anatomy and the surgical skills. Thus, operator factor is brought to a minimum. Throughout the entire procedure, strict asepsis and field sterilization is emphasized.

The surgeon places the thread using 5 standard approaches (see procedure). In this way the aesthetic outcomes are more predictable. Surgeons can have better surgical handling in the field by improvising the surgery of each individual based on the standard techniques. Apart from home care counseling, routine structured follow-ups are helpful as well (one week, two weeks and four weeks after the surgery). We believe this will facilitate reporting of any issues related to the recovery and early intervention if necessary.

\section{Conclusion}

Barb suspension thread surgery is a generally safe procedure compared with most other aesthetic procedures. Patient factor, 
operator factor, material and surgical field can contribute to the incidence of adverse outcomes. With careful selection of candidates, well-planned procedure and respect to the sterility of surgical field and individual anatomical structures, majority of the incidents are avoidable. Clear post-operative care instruction and prompt intervention should issues arise are essential.

\section{References}

1. Tavares J. D. P, Oliveira C. A. C. P, Torres R. P, et al. Facial thread lifting with suture suspension. Brazilian Journal of Otorhinolaryngology. 2017; 83: 712-719.

2. Annual report on plastic surgery statistics from American Society of Plastic Surgeons 2016.

3. Sulamanidze MA, Fournier PF, Paikidze TG, et al. Removal of facial soft tissue ptosis with special threads. Dermatol Surg. 2002; 28: 367-371.

4. Piero Fundaro, the Invisible Lift (book)

5. Kalyan R, et al. The Efficacy of Polycaprolactone Threads in Zygomatic and Mandibular Lifting: Consecutive Study from a Single Practitioner's Experience. Amuso Aesthetic Medicine. 2015.

6. Yeo S. H, Lee Y. B, Han D. G. Early Complications from Absorbable Anchoring Suture Following Thread-Lift for Facial Rejuvenation. Archives of Aesthetic Plastic Surgery. 2017; 23: 11.

7. KC Hau. Malar Reshaping (MR) technique for Anterior Projection in Asian faces using bidirectional barb thread suspension surgery. eposter and abstract. WCD 2019.

8. Alam M. H, Kakar R. S, Nodzenski M. A, et al. Multicenter Prospective Cohort Study of the Incidence of Adverse Events Associated With Cosmetic Dermatologic Procedures. JAMA Dermatology. 2015; 151: 271.

9. Gupta V, Parikh R, Nguyen L, et al. Is Office-Based Surgery Safe? Comparing Outcomes of 183,914 Aesthetic Surgical Procedures Across Different Types of Accredited Facilities. Aesthetic Surgery Journal. 2016; 37: 226-235.

10. Savoia A, Accardo C, Vannini F, et al. Outcomes in Thread Lift for Facial Rejuvenation: a Study Performed with Happy Lift $^{\mathrm{TM}}$ Revitalizing. Dermatology and Therapy. 2014.

11. Bertossi D, Botti G, Gualdi A, et al. Effectiveness, Longevity, and Complications of Facelift by Barbed Suture Insertion. Aesthetic Surgery Journal. 2018; 39: 241-247.

12. Matarasso A, Rosen A. D. New and Emerging Uses of Barbed Suture Technology in Plastic Surgery. Aesthetic Surgery Journal. 2013; 33.

13. Fundaro $\mathrm{P}, \mathrm{KC}$ Hau. INNOVATIVE MINIMAL INVASIVE TECHNIQUES IN FACIAL RESHAPING USING BARB SUSPENSION THREAD SURGERY. IMCAS Educational blog. 2018.

14. Byrd HS, Barton FE, Orenstein HH, et al. Safety and efficacy in an accredited outpatient plastic surgery facility: a review of 5316 consecutive cases. Plast Recontr Surg. 2003; 112: 636641. 